\title{
Eye movement parameters while reading show cognitive processes of structural analysis of written speech
}

\author{
Alexander V. Latanov ${ }^{\mathrm{a}^{*}}$, Victor N. Anisimov ${ }^{\mathrm{a}}$, Alexander M. Chernorizov ${ }^{\mathrm{b}}$ \\ ${ }^{a}$ Biology Faculty, Lomonosov Moscow State University, Moscow, Russia \\ ${ }^{\mathrm{b}}$ Psychology Faculty, Lomonosov Moscow State University, Moscow, Russia \\ *Corresponding author. E-mail: latanov@neurobiology.ru
}

This paper gives an overview of the published data on eye movement parameters while reading sentences in different languages with both local and global syntactic ambiguity. A locally ambiguous sentence contains a syntactically problematic phrase that leads to only one interpretation, while a globally ambiguous sentence has more than one distinct interpretation. In the first case the ambiguity persists only to the end of the sentence, when it is successfully resolved; in the second case the ambiguity is still present after reading the whole sentence. The obvious difficulty in analyzing the structure of locally and globally ambiguous sentences leads to increased reading time compared with unambiguous sentences. The syntactic ambiguity increases two major parameters: the fixation duration when reading words critical for interpreting the sentence, and the frequency of regressive saccades to reread those words. The reading time for critical words, disambiguating the local ambiguity, depends on the principle of early/late closure (i.e., high/low attachment): preferring a recurrent pattern to associate the critical word with a distant or closer word, respectively (as determined by its position in the sentence), and differs across languages. The first study of eye movement parameters in reading globally syntactic ambiguous sentences in the Russian language is reported in this paper. Our findings open up the prospects of quantitative studies of syntactic disambiguation in Slavonic and Romano-Germanic languages.

Keywords: reading, psycholinguistics, syntactic ambiguity, gaze fixations, regressive saccades, review

Language and linguistic activity, taken in the whole variety of their types (speech, writing, listening, and reading) and being among the most complex forms of higher cognitive functions, have a number of complex physiological and cognitive mechanisms. Consequently, they are the subject of several disciplines, including physiology, psychology and psycholinguistics (Luria, 1975; Leontiev, 1997; Baars, 2007). The founder of generative grammar theory, N. Chomsky, laid down the theoretical foundations for studying cognitive difficulties in communication connected with 
linguistic form (or verbal expression). A special type of this broader issue is the problem of the origin of and ways of disambiguating syntactic ambiguity in language.

Reading is a highly complicated linguistic activity, for it is not only a perceptual and a motor but also a cognitive process. At each moment while reading, incoming visual information is continuously recognized and eye movements are prepared and executed; each of these is made up of different stages. The process of reading involves a set of sensory, motor, and mental processes (attention, memory, pattern recognition, decision making) related to the processing of visually perceived words. While reading, the eyes make a series of rapid movements (called saccades), separated by periods of time in which the eyes are relatively still (called fixations). It is only during fixations that the new visual information is encoded from the text, because vision is functionally suppressed during saccades. The process of recognizing signs that comprise morphemes and words occurs during fixations only. As a result, the visual properties of the letters are converted to orthographic and phonological patterns that are further processed into linguistic information that eventually leads to understanding of the text.

The anatomical and functional substrate of these processes constitutes hierarchically organized wide areas of the frontal, temporal, and parietal lobes (Luria, 1975; Vigneau et al., 2006). The contemporary framework for understanding the mechanisms and localization of speech functions is based on neuropsychological (Luria, 1975; Ellis, 2012) and neurophysiological data obtained with functional magnetic resonance imaging (fMRI) (Hagoort, 2005; Hasson \& Small, 2008) and evoked potentials (Kutas \& Hillyard, 1984; Hagoort et al., 2004; Steinhauer \& Connolly, 2008). But neurophysiological methods impose certain limitations on experimental study of reading, since they require that eye movements be eliminated from investigation. Eye movements produce significant artifacts and thereby mask the neuronal signals of the actual speech process. In real life, reading is carried out with the help of eye movements, and in such conditions the processes of motor control are inevitably superimposed on the speech analysis processes, which makes it impossible to separate these effects. However, the parameters of saccades and fixations indirectly represent the brain's linguistic processes because they are closely related to the cognitive functions (attention, memory, letter pattern recognition, decision making) that achieve recognition and comprehension of written language (Clifton et al., 2007). The undeniable advantage of recording eye movement during reading consists in the possibility of tracking the gaze position in real time; therefore, for several decades, eye movement parameters have been widely used to study linguistic processes (Rayner, 1998; Underwood, 2005; Clifton et al., 2007; Rayner et al., 2012).

The recording of eye movements makes it possible to determine the time it takes to read various parts of a text. When associating the time spent on a particular phrase with its linguistic features, it is possible to draw certain conclusions about the physiological and mental processes involved in recognition and comprehension this phrase. The gaze position points at the phrase currently being processed, and the time spent on it manifests the involvement of mental activity. These assumptions have been confirmed by many experiments showing that the linguistic peculiarities of the phrase determine the time spent to read it (Underwood, 2005; Rayner et al., 2006, 2012; Clifton et al., 2007; Rayner, 2009). Thus, eye movement parameters and the mental processes associated with analyzing the currently per- 
ceived and processed phrase are assumed to be related to each other, as is supported by a large body of experimental data and experience in psycholinguistic studies (Underwood, 2005; Rayner et al., 2006; Clifton et al., 2007; Rayner, 2009).

\section{The effects of lexical ambiguity on eye movements during reading}

Studies in the English language demonstrate that fixation duration while reading certain phrases of a sentence and consequently the total reading time for some particular phrase depend on the lexical properties of the words that present special difficulty for interpretation (Rayner et al., 1977, 2006; Rayner \& Duffy, 1986; Clifton et al., 2007; Reichle et al., 2007). For example, while reading the most frequently used nouns in the English vocabulary (more than 100 words/million in the English corpus dictionary, the CELEX English lexical database), fixations are shorter by 25-40 ms than fixations while reading the rare nouns (less than 10 words/million) (Rayner \& Duffy, 1986; Rayner et al., 2006; Clifton et al., 2007). Semantic properties of the words (e.g., predictability) also affect the fixation durations. While reading highly plausible words they become shorter by $40 \mathrm{~ms}$ and more than fixation durations while reading less plausible words (Rayner et al., 2006; Clifton et al., 2007). Moreover, fixation durations significantly increase when reading semantic anomalies, misspellings, and pseudo-words, compared to the fixation duration of the expected words (Rayner et al., 2006; Clifton et al., 2007). Processing a polysemantic word (lexical ambiguity) also increases reading time (Rayner \& Duffy, 1986; Clifton et al., 2007). These results imply that when reading unusual phrases, their linguistic analysis is slowed down in terms of various parameters, because additional mental processes are involved. Higher attention activation and increased load on mnemonic processes inhibit decision making. These processes are represented by electrical activity of the brain such as evoked potentials (Kutas \& Hillyard, 1984; Hagoort et al., 2004; Steinhauer \& Connolly, 2008) and are correlated with the hemodynamics of certain brain areas as shown by fMRI studies (Hagoort, 2005; Hasson, Small, 2008).

\section{Eye movements in syntactic analysis of locally ambiguous sentences during reading}

Structural features and syntactic variables of the sentences also influence eye movement parameters (Rayner, 1998; Clifton et al., 2007), as reported in a substantial number of articles (for a review, see Clifton et al., 2007). The number of fixations, their durations, saccadic amplitudes, and the frequency of regressive saccades (regressions) that are executed during the second path of reading certain phrases, are associated with certain difficulties in interpreting the sentence structure and, therefore, comprehension of the text. In general, different types of syntactic ambiguities slow down the reading of ambiguous sentences compared to unambiguous sentences in different languages (English, Spanish, German, French, and some others) (Frazier \& Rayner, 1982; Cuetos \& Mitchell, 1988; Schriefers et al., 1995; FrenckMestre \& Pynte, 1997; Traxler et al., 2002; Staub, 2010).

Two forms of syntactic ambiguity are differentiated in linguistics: local and global ambiguity. Local ambiguity is temporary until it is resolved after reading 
the phrase following the critical one; this leads to one distinct interpretation of the processed sentence. The globally ambiguous sentence has two equally possible interpretations. However, most studies of eye movements while reading focus on disambiguation of local syntactic ambiguity (Frazier \& Rayner, 1982; Cuetos \& Mitchell, 1988; Traxler et al., 2002; Staub, 2010).

Different eye movement parameters clearly represent this disambiguation process. This means that the time for reading the critical words in locally ambiguous sentences is longer than the time for reading functionally analogous word combinations of unambiguous sentences (Frazier \& Rayner, 1982; Cuetos \& Mitchell, 1988; Staub, 2010). Consider the example of local ambiguity that was discussed in the pioneering work by Frazier and Rayner (1982, p. 179). While reading a clause of the sentence Since Jay always jogs a mile (Figure 1) the noun a mile is ambiguous. It could be defined as part of either the first or the second clause, and the reader can't choose the model of interpretation. Sentences $1 \mathrm{a}$ and $1 \mathrm{~b}$ give the possible interpretations in a more explicit manner. In sentence 1a, the demonstrative pronoun this at the beginning of the second part of the sentence forces the reader to define the word a mile as the direct object of the verb jogs. In sentence $1 \mathrm{~b}$, a mile is the subject of the verb seems in the second clause and the sentence has another interpretation. The authors gave the subjects 16 pairs of structurally similar sentences to read.

(1) Since Jay always jogs a mile...

\section{$243 \quad 268248$}

(1a) Since Jay always jogs a mile (this) seems like a short distance to him

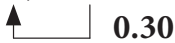

$245 \quad 283267$

(1b) Since Jay always jogs a mile (seems) like a very short distance to him

Figure 1. Examples of two sentences with local syntactic ambiguity (Frazier \& Rayner, 1982). The numbers above words indicate the average fixation durations (ms) during reading them (ibid., Table 4, p.103). The arrows indicate the regressions for rereading critical words and the numbers nearby indicate frequency of regressions of the total number of sentences (ibid., Table 9, p. 199).

In English, the comprehension of syntactically ambiguous sentences is driven by two very general parsing strategies: late closure $(L C)$ and minimal attachment (Frazier \& Rayner, 1982). These strategies are defined as follows:

"Late closure: When possible, attach the incoming lexical items into the clause or phrase currently being processed," i.e., the lowest possible nonterminal node dominating the last item analyzed.

"Minimal attachment: Attach the incoming material into the phrase-marker being constructed using the fewest nodes consistent with the well-formedness rules of the language," i.e., the principle of least links ("shortest path") between the words.

$L C$ strategy implies that in the phrase jogs a mile (Figure 1, sentence 1a) the item currently being processed, jogs, is added to the direct object, a mile. In other 
words, in this case the lowest possible nonterminal node is established; it links the item - jogs - and the latest item analyzed - a mile. Sentence $1 \mathrm{~b}$ is an example of an ambiguous sentence with early closure (EC) or high attachment, which is in clear correlation with the already formed patterns, typical for the language being studied.

Fixations during reading the critical words (i.e., disambiguating the local ambiguity) this (1a) and seems (1b) were found to be on average longer than fixations on the surrounding words. Thus the fixation duration in reading the item this (268 $\mathrm{ms})$, solving the target ambiguity in 1 a with $L C$, is shorter than the average fixation duration on the item seems $(283 \mathrm{~ms})$, solving the ambiguity in $1 \mathrm{~b}$ with $E C$. In addition, the readers sometimes execute regressions to reread some phrases of the sentences. These saccades are often (about $2 / 3$ of their total number) executed by the subjects to return to the critical words this (1a) and seems (1b) in order to verify interpretation of the sentence. It should be noted that regressions are less frequent when reading sentences with $L C(0.30)$, the dominant closure pattern in English, than with $E C(0.38)$.

The increased fixation durations while reading the critical words as described by Frazier and Rayner (1982) and supported by other studies (Cuetos \& Mitchell, 1988; Staub, 2010; Clifton et al., 2007) are connected with an additional cognitive load, voluntary attention and working memory being involved with interpreting the whole sentence. At the same time, the execution of regressions and additional fixations for rereading an ambiguous phrase signify a reanalysis of the primary sentence interpretation.

The first comparative study of reading similar sentences with local ambiguity was conducted in English and Spanish with native speakers of both languages (Carreiras \& Clifton, 1999). However, the eye movement parameters for these languages turned out to be opposite. Fixation durations in reading the critical words in English were shown to rise when subjects were reading sentences with $E C$, whereas in Spanish this phenomenon was shown for reading sentences with $L C$. These results suggest that in Spanish, unlike English, the principle of attachment of lexical units in resolving local ambiguity dominates, namely EC or high attachment.

\section{Eye movements in syntactic analysis of globally ambiguous sentences during reading}

Eye movement parameters in disambiguating global syntactic ambiguity have only been investigated in a few studies, still mostly in English (Traxler et al., 1998; Van Gompel et al., 2001, 2005). A special case of global ambiguity is complex sentences with relative clauses, as in the well-known example: Someone shot the servant of the actress who was on the balcony (its equivalent in Russian: Некто застрелил служанку актрисы, которая стояла на балконе). In giving the answer to the question Who stood on the balcony? the English speakers often chose the second noun (the actress) (Cuetos \& Mitchell, 1988; Carreiras \& Clifton, 1999; Staub, 2010), while Russian speakers chose the first noun (the servant) more often (Fedorova \& Yanovich, 2004). Otherwise stated, the English readers still prefer the LC strategy when interpreting sentences with global ambiguity, as was the case in sentences with local ambiguity (Frazier \& Rayner, 1982). Apart from English, the LC strategy also prevails in Portuguese (Brazil), Norwegian, Swedish, Finnish, Arabic, and Romanian 
(Fodor, 1998). However, in other languages, including Russian the opposite trend is manifested. The EC strategy is preferred in French, Greek, Japanese, Spanish, Dutch, German, Polish, Croatian, and Bulgarian (Cuetos \& Mitchell, 1988; Sekerina, 1997; Fodor, 1998; Carreiras \& Clifton, 1999; Fedorova \& Yanovich, 2004).

Traxler and coauthors (Traxler et al., 1998; Van Gompel et al., 2001, 2005) noted that the reading time for complex sentences with relative clauses containing global syntactic ambiguity is shorter compared with local syntactic ambiguity, but is still somewhat longer than the reading time of sentences without any ambiguity. Based on the their results, Traxler and coauthors put forward the hypothesis that global syntactic ambiguity does not induce significant difficulties in comprehending the sentence and its further interpretation is likely to be predetermined. Difficulty in analyzing sentences with global ambiguity as well as those with local ambiguity involves additional mental effort and, consequently, increases the reading time.

Until recently there were no studies of eye movement parameters while reading sentences with global syntactic ambiguity in Slavonic languages. The first study in Russian (Anisimov et al., 2013, 2014) with the original high frequency $(250 \mathrm{~Hz})$ eye tracker (Anisimov et al., 2012) was carried out by the authors of the present paper. In our experiments, 28 subjects read 40 complex sentences with feminine relative clauses with global syntactic ambiguity (Figure 2, sentence 2 a). To verify our findings, we included 40 similar control sentences, in a random order, without any ambiguity being given to subjects (Figure 2 , sentence $2 \mathrm{~b}$ ).

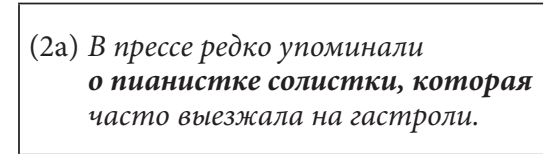

English translation:

(2a) The press rarely mentioned the pianist of the soloist, who often goes on tour. (2b) Студент негромко говорил со своей племянницей, которая ему не нравилась.

English translation:

(2b) The student spoke softly with his niece, whom he did not like.

Figure 2. Two sentences with global syntactic ambiguity (Anisimov et al., 2013, 2014). All sentences were presented in three lines, the second line (in 2a) containing the global syntactic ambiguity.

We compared eye movement parameters while reading the second line of the syntactically ambiguous sentences ( $2 \mathrm{a})$ and the control sentences with only one interpretation (2b). All parameters were averaged over all subjects and all sentences. We found significant differences between eye movement parameters while reading ambiguous and control sentences (Table 1). We found a similar effect of ambiguity on all eye movement parameters, as was previously reported for other languages.

As already mentioned, the EC principle dominates in Russian, particularly in resolving ambiguity of a sentence with a relative clause (Fodor, 1998; Fedorova \& Yanovich, 2004). In our study, the average proportion of EC for all sentences was 0.67 . A similar proportion of $E C$ was also reported for some other languages (Cuetos \& Mitchell, 1988; Sekerina, 1997; Fodor, 1998; Carreiras \& Clifton, 1999; Fedo- 
rova \& Yanovich, 2004). According to the studies of global syntactic ambiguity disambiguation in English, the proportion of $L C$ is the same 0.67 (Frazier \& Rayner, 1982, Carreiras \& Clifton, 1999; Clifton et al., 2007).

Table 1. Eye movement parameters in reading second lines in ambiguous and unambiguous sentences (Anisimov et al., 2014).

\begin{tabular}{lccc}
\hline \multicolumn{1}{c}{ Parameter } & $\begin{array}{c}\text { Ambiguous } \\
\text { sentences }\end{array}$ & $\begin{array}{c}\text { Unambiguous } \\
\text { sentences }\end{array}$ & $p$ \\
\hline Total reading time, ms & $1,393 \pm 20(1,169)$ & $1,195 \pm 14(1,169)$ & $<0.00001$ \\
Number of fixations per string & $5.29 \pm 0.05(1,169)$ & $4.72 \pm 0.04(1,169)$ & $<0.00001$ \\
Frequency of regressions per string & $0.60 \pm 0.03(1,169)$ & $0.32 \pm 0.02(1,169)$ & $<0.00001$ \\
Fixation durations, ms & $207 \pm 1(5,964)$ & $200 \pm 1(5,326)$ & $<0.00001$ \\
\hline
\end{tabular}

The data averages $(\mathrm{M} \pm \mathrm{SEM})$ were calculated for all subjects and all sentences. The size of the sample is given in parentheses. The influence of the type of the sentence with ambiguity levels "ambiguous" and "unambiguous" on all parameters (at the significance level $p$ ) was evaluated by the ANOVA repeated measures method.

Our results open the perspective of objective comparative study of linguistic processes and their mental counterparts, particularly ways to resolve syntactic ambiguity in Slavonic and Romano-Germanic languages.

\section{Acknowledgments}

This research was supported by RFBR grant No. 15-04-05745.

\section{References}

Anisimov, V.N., Fedorova, O.V., \& Latanov, A.V. (2013). Parametry dvizheniia glaz kak marker razresheniia globalnoi sintakticheskoi neodnoznachnosti v russkom yazyke [Eye movement parameters as a marker of the disambiguation of global syntactic ambiguity in Russian]. Kognitivnaia nauka v Moskve: novye issledovaniia. Materialy konferentsii [Cognitive sciences in Moscow: New studies. Abstracts] (pp. 24-28). Moscow: OOO Buki Vedi.

Anisimov, V.A., Fedorova, O.V., \& Latanov A.V. (2014). Eye movement parameters in reading sentences with syntactic ambiguities in Russian. Human Physiology, 40(5), 521-531. doi: 10.1134/S0362119714040033.

Anisimov, V.N., Ermachenko, N.S., Ermachenko, A.A., Tereschenko, L.V., \& Latanov, A.V. (2012). Eksperimentalnyi kompleks dla odnovremennoi registratsii dvizhenii glaz i elektroentsefaligrammy [Experimental setup for synchronous recording of eye movements and EEG]. Izvestiia SFedU [Southern Federal University Bulletin]. Engineering Sciences, 11(136), $116-120$.

Baars, B.J. (2010). Language. In B.J. Baars, \& N.M. Gage (Eds.), Cognition, brain, and consciousness. Introduction to cognitive neuroscience (pp. 371-396). Amsterdam, London, NY: Academic Press. doi: 10.1016/B978-0-12-375070-9.00011-5 
Carreiras, M., \& Clifton, C. (1999). Another word on parsing relative clauses: Eyetracking evidence from Spanish and English. Memory \& Cognition, 27(5), 826-833. doi: 10.3758/ BF03198535

Chomsky, N. (1962). Sintakticheskie struktury [Syntactic structures]. In V.A. Zvegintsev (Ed.), Novoe $v$ lingvistike [New in linguistics] (Vol. 2, pp. 412-527). Moscow: Foreign Literature Publishing.

Chomsky, N. (1972). Yazyk i myshlenie [Language and mind]. Moscow: Moscow University Press.

Clifton Jr., C., Staub, A., \& Rayner, K. (2007). Eye movements in reading words and sentences. In R.P.G. Van Gompel, M.H. Fischer, W.S. Murray, \& R.L. Hill (Eds.), Eye movements: A window on mind and brain (pp. 341-371). Oxford, UK: Elsevier. doi:10.1016/B978008044980-7/50017-3

Cuetos, F., \& Mitchell, D. (1988). Cross-linguistic differences in parsing: Restrictions on the use of the late closure strategy in Spanish. Cognition, 30(1), 73-105. doi:10.1016/0010-0277(88)90004-2

Ellis, A.W. (2012).The acquisition, retention, and loss of vocabulary in aphasia, dementia, and other neuropsychological conditions. In M. Faust (Ed.), The handbook of the neuropsychology of language (Part 2, pp. 635-660). Oxford, UK: Wiley-Blackwell. doi:10.1111/ b.9781444330403.2012.00035.x

Fedorova, O.V., \& Yanovich, I.S. (2004). Ob odnom tipe sintakticheskoi mnogoznachnosti, ili Kto stoyal na balkone [One type of syntactic ambiguity, or who stood on the balcony]. In Komputernaia lingvistika i intellektualnye tekhnologii: Trudy mezhdunarodnoi konferentsii 'Dialog 2004' [Computer linguistics and intellectual technologies: Abstracts of the international conference 'Dialog 2004'] (pp. 644-649). Moscow: Nauka.

Fodor, J.D. (1998). Learning to parse? Journal of Psycholinguistic Research, 27(2), 285-319. doi: 10.1023/A:1023258301588

Frazier, L., \& Rayner, K. (1982). Making and correcting errors during sentence comprehension: Eye movements in the analysis of structurally ambiguous sentences. Cognitive Psychology, 14, 178-210. doi: 10.1016/0010-0285(82)90008-1

Frenck-Mestre, C., \& Pynte, J. (1997). Syntactic ambiguity resolution while reading in second and native languages. The Quarterly Journal of Experimental Psychology, 50A(1), 119-148. doi: $10.1080 / 027249897392251$

Hagoort, P. (2005). On Broca, brain, and binding: a new framework. Trends in Cognitive Science, 9(9), 416-423. doi: 10.1016/j.tics.2005.07.004

Hagoort, P., Hald, L., Bastiaansen, M., \& Petersson, K. (2004). Integration of word meaning and world knowledge in language comprehension. Science, 304(5669), 438-441. doi: 10.1126/ science. 1095455

Hasson, U., \& Small, S.L. (2008). Functional magnetic resonance imaging (fMRI) research of language. In B. Stemmer \& H.A. Whitaker (Eds.). Handbook of the neuroscience of language (pp. 81-89). Amsterdam, Netherlands: Elsevier. doi: 10.1016/B978-0-08-045352-1.00008-2

Kutas, M., \& Hillyard, S. (1984). Brain potentials during reading reflect word expectancy and semantic association. Nature, 307(5947), 161-163. doi: 10.1038/307161a0

Leontiev, A.A. (1997). Osnovy psikholingvistiki [Fundamentals of psycholinguistics]. Moscow: Smysl.

Luria, A.R. (1975). Osnovnye problemy neirolingvistiki [Basic problems of neurolinguistics]. Moscow: Moscow State University Publishing.

Rayner, K. (1977). Visual attention in reading: Eye movements reflect cognitive processes. Memory \& Cognition, 5(4), 443-448. doi: 10.3758/BF03197383

Rayner, K. (2009). Eye movements and attention in reading, scene perception and visual search. The Quarterly Journal of Experimental Psychology, 62(8), 1457-1506. doi: 10.1080/ 17470210902816461 
Rayner K., Pollatsek A., Ashby J., \& Clifton Jr., C. (2012). The psychology of reading (2nd ed). NY: Psychology Press. doi: 10.1002/9781118133880.hop204019

Rayner, K. (1998) Eye movements in reading and information processing: 20 years of research. Psychological Bulletin, 124(3), 372-422. doi: 10.1037//0033-2909.124.3.372

Rayner, K. \& Duffy, S. (1986). Lexical complexity and fixation times in reading: Effects of word frequency, verb complexity, and lexical ambiguity. Memory \& Cognition, 24(3), 191-201. doi: 10.3758/BF03197692

Rayner, K., Reichle, E., Stroud, M., Williams, C., \& Pollatsek, A. (2006). The effect of word frequency, word predictability, and font difficulty on the eye movements of young and older readers. Psychology and Aging, 21(3), 448-465. doi: 10.1037/0882-7974.21.3.448

Reichle, E. D., Pollatsek, A., \& Rayner, K. (2007). Modeling the effects of lexical ambiguity on eye movements during reading. In R.P.G. Van Gompel, M.F. Fischer, W.S. Murray, \& R.L. Hill (Eds.), Eye movements: A window on mind and brain (pp. 271-292). Oxford, England: Elsevier. doi:10.1016/B978-008044980-7/50014-8

Schriefers, H., Friederici, A., \& Kuhn, K. (1995). The processing of locally ambiguous relative clauses in German. Journal of Memory and Language, 34(4), 499-520. doi: 10.1006/ jmla.1995.1023

Sekerina, I. (1997). The late closure principle vs. the balance principle: Evidence from on-line processing of ambiguous Russian sentences. In Proceedings of the second European conference on formal description of Slavic languages. Current approaches to formal Slavic languages. Potsdam Meeting (pp. 205-217). Frankfurt: Peter Lang.

Staub, A. (2010). Eye movements and processing difficulty in object relative clauses. Cognition, 116(1), 71-86. doi: 10.1016/j.cognition.2010.04.002

Steinhauer, K., \& Connolly, J.F. (2008). Event-related potentials in the study of language. In B. Stemmer \& H.A. Whitaker (Eds.). Handbook of the neuroscience of language (pp. 91-104). Amsterdam: Elsevier. doi: 10.1016/B978-0-08-045352-1.00009-4

Traxler, M., Pickering, M., \& Clifton, C. (1998). Adjunct attachment is not a form of lexical ambiguity resolution. Journal of Memory and Language, 39(4), 558-592. doi:10.1006/ jmla.1998.2600

Traxler, M.J., Morris, R.K., \& Seely, R.E. (2002). Processing subject and object relative clauses: Evidence from eye movements. Journal of Memory and Language, 47(1), 69-90. doi: 10.1006/jmla.2001.2836

Underwood, G. (2005). Cognitive processes in eye guidance. Oxford, UK: Oxford University Press. doi: 10.1093/acprof:oso/9780198566816.001.0001

Van Gompel, R., Pickering, M., \& Traxler, M. (2001). Reanalysis in sentence processing: Evidence against current constraint-based and two-stage models. Journal of Memory and Language, 45(2), 225-258. doi:10.1006/jmla.2001.2773

Van Gompel, R., Pickering, M., Pearson, J., \& Liversedge S. (2005). Evidence against competition during syntactic ambiguity resolution. Journal of Memory and Language, 52(2), 284-307. doi:10.1016/j.jml.2004.11.003

Vigneau, M., Beaucousin, V., Hervé, P., Duffau, H., Crivello, F., Houde, O., Mazoyer, B., \& Tzourio-Mazoyera, N. (2006). Meta-analyzing left hemisphere language areas: Phonology, semantics, and sentence processing. Neuroimage, 30(4), 1414-1432. doi: 10.1016/j. neuroimage.2005.11.002

Original manuscript received October 01, 2015 Revised manuscript accepted February 15, 2016 First published online June 30, 2016 


\title{
The semantic structure of gratitude
}

\author{
Alexander V. Smirnov, Alyona G. Obolenskaya, Ravil A. Valiev ${ }^{*}$ \\ Psychology Institute, Ural State Pedagogical University, Ekaterinburg, Russia \\ *Corresponding author. E-mail: rw1973@mail.ru
}

In the modern social and economic environment of Russia, gratitude might be considered an ambiguous phenomenon. It can have different meaning for a person in different contexts and can manifest itself differently as well (that is, as an expression of sincere feelings or as an element of corruption). In this respect it is topical to investigate the system of meanings and relationships that define the semantic space of gratitude. The goal of the study was the investigation and description of the content and structure of the semantic space of the gratitude phenomenon as well as the determination of male, female, age, and ethnic peculiarities of the expression of gratitude. The objective was achieved by using the semantic differential designed by the authors to investigate attitudes toward gratitude. This investigation was carried out with the participation of 184 respondents (Russians, Tatars, Ukrainians, Jews) living in the Russian Federation, Belarus, Kazakhstan, Tajikistan, Israel, Australia, Canada, and the United Kingdom and identifying themselves as representatives of one of these nationalities. The structural components of gratitude were singled out by means of exploratory factor analysis of the empirical data from the designed semantic differential. Gender, age, and ethnic differences were differentiated by means of Student's $t$-test. Gratitude can be represented by material and nonmaterial forms as well as by actions in response to help given. The empirical data allowed us to design the ethnically nonspecified semantic structure of gratitude. During the elaboration of the differential, semantic universals of gratitude, which constitute its psychosemantic content, were distinguished. Peculiarities of attitudes toward gratitude by those in different age and gender groups were revealed. Differences in the degree of manifestation of components of the psychosemantic structure of gratitude related to ethnic characteristics were not discovered. The semantic universals of gratitude are grouped into the components of its semantic structure: intentional, relational, essential, and expressive. These structural elements are present in the representatives of all the nationalities who participated in the study. The men were more likely than the women to demonstrate the instrumental understanding of gratitude. The women were more likely than the men to reflect humanistic ideas of gratitude. The romantic and noble idea of gratitude was dominant in representatives of the younger generation (18-year-olds). The young adults (19-to-25-year-olds) tended to demonstrate social realism to a larger extent than respondents in the other age groups. In respondents who were 26-years-old and above, humanistic assessment and collectivist values with respect to gratitude significantly decreased.

Keywords: gratitude, culture, sociocultural environment, semantic space, economic environment 


\section{Introduction}

In the current geopolitical situation, when religion, nationality, and ethnocultural differences of peoples are used as fields and tools for inciting conflicts, the scientific community responds to these adverse but stable trends with an abundance of research. The leitmotif for the research is the aspiration to reveal the genesis, the content, and ways of minimizing ethnocultural, religious, and ethnic conflicts (Agaev, 2013; Erokhin, 2013; Perin, 2003; Ryazanov, 2014; Sampiev, 2010; Shiryakov, 2014; Tengizova, 2014). The specifics of national character and national culture as well as religious/confessional differences and ethnic characteristics are being studied (Bajer, 2014; Belyakova \& Grigoryan, 2010; Bryanskaya, 2011; Klimenko, 2011; Muchkaev, 2012; Nadya, 2011; Rakhmatullina, 1999; Ri, 2014). In this article the ethnically nonspecified semantic structure of gratitude as well as peculiarities of the views on gratitude in different age and gender groups are presented. A theoretical framework and practical tools for further research of the gratitude phenomenon are elaborated.

\section{The socioeconomic environment as a semantic space}

In anthropology, cultural studies, and social psychology, a subjective semantic space is considered to exist as a system of categories of individual consciousness by means of which a person evaluates and classifies various objects, concepts, and events. It is postulated that, being immersed in a cultural, information, socioeconomic, and political environment, a person creates a system of perception and understanding of the surrounding reality and attitudes toward it (Zhukova, 2010). Internal and external contexts of the system are differentiated. The internal context is defined as specific features of the person's individuality represented at all levels. This individuality is understood as a set of all of one's unique human characteristics as an individual and personality. The external context is viewed as a system of social, sociocultural, socioeconomic, spatial and temporal, political, and other characteristics of the environment in which a person lives. The internal and external contexts in their interaction perform the meaning-forming function of all human life at each level of psychic reflection (Zhukova, 2010) and define a person's behavior and activity on the basis of the principle of the unity of consciousness and activity (Serkin, 2008). As a result the study of everyday ideas about the phenomenon of gratitude under the current economic conditions by means of psychosemantic methods allows us to determine what kind of internal semantic space (system of significations) is formed with respect to gratitude and what kind of stimulating effect it (the system of significations) produces.

Further we will consider here the relationship between the concepts meaning and signification in the context of psychosemantic methods. One's attitude toward the world's objects, deep structures of subjective experience, is presented in the form of sense relations ("a phenomenon for me," "the meaning of the event for me") (Serkin, 2004). Taking into account individual subjective experience, each person evaluates the meaning of stimuli and defines "meaning for oneself," which is close to the notion of sense. In group research, in contrast, the description of a group of motives is introduced and is followed by a statistical grouping of generalized characteristics of intersubjective assessment of the stimulus; this idea is close to the 
concept of signification. Thus, the notion of sense is used in studies of individual subjective experience, while the concept of signification is employed in group assessment (Serkin, 2004).

Because this article presents the results of group studies, we will use the notion of signification. Signification is understood as a unit that has denotative, operational, and affective-motivational content. This content allows us to consider signification as a unit of psychological analysis that is able to regulate activities and behavior in accordance with defined objectives, motives, and circumstances (Serkin, 2004).

\section{Research objectives}

Traditionally, the study of various phenomena in psychosemantics involves a number of stages before a researcher eventually receives the necessary results. For example, investigation of gratitude might include the study of relevant fiction, published journals, and other literature that describes the idea of gratitude; the study of everyday concepts and culturally-determined concepts, including mythological (fairy-tale) ones; and academic ideas and expert assessment (Serkin, 2004, 2008).

Taking into the account the facts mentioned above, we specified the following objectives of the study.

1. Collection of data on everyday notions of gratitude.

2. Identification of both the system of gratitude significations in the modern information and cultural environment regardless of ethnicity and the modeling of representations of the phenomenon of gratitude in people's minds.

3. Definition of the semantic space of the phenomenon of gratitude. Elicitation of the statistically-based structure of gratitude.

4. Determination of male, female, age, and ethnic peculiarities of the expression of gratitude.

\section{Method}

To achieve the research objectives, we designed our semantic differential for investigating attitudes toward gratitude. The method had two steps. The first one was to collect data on the everyday ideas of gratitude; the second one was to define semantic universals reflecting the image of gratitude and the modeling of its structure.

\section{Data collection of everyday notions of gratitude}

At this stage participants were requested to give free-form answers to the following questions: What is human gratitude? What forms might it have? What content might it have? What expresses gratitude? What is the essence of human gratitude? The answers to the questions were both separate and monosyllabic as well as in the form of mini-essays (coherent speculations).

The selection and surveying of the respondents was random. The respondents were interviewed both in person and in absentia (with the use of online interviews). At this stage the study involved 118 people aged 18 to 56 with an approximately equal ratio of male and female participants of different nationalities and from different social strata. 
From the material received (more than 12,000 words and phrases) 642 thematic word-forms were distinguished; they reflected the everyday understanding of gratitude and were different in form, content, and ways of expressing human relations. The procedure included the use of the content analysis software ContPro 6.1 , correlation analysis, and analysis of meanings.

Then the forms that were encountered more than once were selected from the 642 word-forms. Sixty word-forms that served as a basis for further study were selected. The frequency distribution of the selected word-forms is characterized as a normal distribution of data.

\section{Definition of semantic universals reflecting views of gratitude and modeling of the structure of gratitude}

With the help of the quantile-percentile selection method 18 word-forms with a maximum frequency of occurrence were selected out of the initial 60 word-forms. These 18 word-forms, first, served as an empirical basis for the design of semantic differential representations of gratitude and, second, formed a theoretical model of the structure of the notion of gratitude. The content of the variables grouped in blocks shows the presence of a particular structure and basic components of the phenomenon of gratitude: essential ("Gratitude is ..."); relational (with respect to others) (“Gratitude ..."); expressive (“Gratitude is expressed ..."); intentional (ex-

\begin{tabular}{|l|c|}
\hline Characteristics & Evaluation \\
\hline Gratitude is ... & \\
\hline experience & 12345678910 \\
\hline attitude & 12345678910 \\
\hline response & 12345678910 \\
\hline expression of warm feelings & 12345678910 \\
\hline expression of goodness & 12345678910 \\
\hline ordinary life phenomenon & 12345678910 \\
\hline acknowledgement for help & 12345678910 \\
\hline Gratitude ... & \\
\hline might be mercenary & 12345678910 \\
\hline might be insincere & 12345678910 \\
\hline might be sparing & 12345678910 \\
\hline has a goal & 12345678910 \\
\hline is addressed to particular people & 12345678910 \\
\hline Gratitude is expressed ... & \\
\hline materially & 12345678910 \\
\hline by an action & 12345678910 \\
\hline by words (is verbalized) & 12345678910 \\
\hline One ... gratitude & \\
\hline would like to receive & 12345678910 \\
\hline would like to express & 12345678910 \\
\hline can measure & 12345678910 \\
\hline Your gender & \\
\hline Your age & \\
\hline Nationality & \\
\hline
\end{tabular}

Here is a list of various features and statements that describe the phenomenon of human gratitude.

Evaluate different characteristics of this phenomenon using the 10-point scale. If the characteristic, in your opinion, is minimally represented, it should be given 1 point, if it is represented to the maximum, it should be given 10 points.

The rest of the evaluation also expresses your opinion of the representation of a particular characteristic. It is requested that you circle the corresponding evaluation. Please, be attentive and fill in all the lines. Thank you!

Figure 1. Survey for evaluating the characteristics of the semantic differential of gratitude and their representations 
pressing intention or direction) ("One ... gratitude”). The elaborated semantic differential (Figure 1) was used to define the semantic space of gratitude, to investigate its statistically-determined structure, and to define peculiarities of attitudes toward gratitude in different gender, age, and ethnic groups. At the next stage of the research this model was tested empirically.

At this stage the study involved 206 people. The data were collected by in-person interviews as well as with the use of the Internet. After the elimination of respondents because of incorrect completion of the survey as well as of representatives of those nationalities the quantity sample of which did not allow including them in statistical calculations, the total sample size was 184 people. The study involved citizens of the Russian Federation, Belarus, Kazakhstan, Tajikistan, Israel, Australia, Canada, and the United Kingdom who identified themselves as representatives of one of the nationalities (Table 1).

Table 1. Nationality and age indicators of the sample

\begin{tabular}{|c|c|c|c|c|c|}
\hline Nationality & Sex & $\begin{array}{l}\text { Age } 18 \\
\text { (youth) }\end{array}$ & $\begin{array}{c}\text { Age 19-25 } \\
\text { (adulthood) }\end{array}$ & $\begin{array}{l}\text { Age 26-56 } \\
\text { (maturity) }\end{array}$ & Total \\
\hline \multirow{2}{*}{ Russian } & Male & 12 & 7 & 47 & \multirow{2}{*}{146} \\
\hline & Female & 36 & 17 & 27 & \\
\hline \multirow{2}{*}{ Tatars } & Male & 1 & - & 1 & \multirow{2}{*}{10} \\
\hline & Female & 2 & - & 6 & \\
\hline \multirow{2}{*}{ Ukrainians } & Male & 1 & 1 & 4 & \multirow{2}{*}{9} \\
\hline & Female & - & 1 & 2 & \\
\hline \multirow{2}{*}{ Jews } & Male & - & - & 14 & \multirow{2}{*}{19} \\
\hline & Female & - & - & 5 & \\
\hline & $\Sigma$ & 52 & 26 & 106 & 184 \\
\hline
\end{tabular}

\section{Results}

Analysis of the normality of the data distribution showed normal distribution of categories in each of the groups (differentiated by gender, age, nationality). Internal consistency of the differential, its reliability, and connection of the semantic categories with the assessment of the gratitude phenomenon defined by Cronbach's $\alpha$ amounted to the index $0.75 \div 0.82\left(\chi^{2}=64.72, p<001\right)$ (the norm is $\alpha=0.65$ ), which indicates good reliability of the method and allowed us to use this method for the investigation of gratitude (Stolin, Bodalev, \& Avanesov, 2002). $\Theta$-reliability of the differential was 0.72 , which also proves its reliability with respect to the diagnostic semantics of gratitude (Stolin, Bodalev, \& Avanesov, 2002). Verification of the representativeness of the sample by the splitting method (even-odd) followed by the test of differences by means of Student's $t$-test (for all 18 universals) showed no difference (by the criterion of sex, age, ethnicity); this result allowed us to extrapolate the results of the sample survey to a large-scale general population (Stolin, Bodalev, \& Avanesov, 2002). 


\section{Elaboration of the semantic space of gratitude and its statistically-based structure}

The model verification was carried out by the factorization method (the method of principal components, a Varimax rotation), and a factor structure was obtained (Tables 2 and 3). The percentage of factor-structure stability was 59\%; the norm was $51 \%$ (Nasledov, 2004/2012). The stability of individual factors was confirmed by the Lewandowskiy method (Lewandowskiy, 1980).

Table 2. Factor structure of the phenomenon of gratitude and its basic components

\begin{tabular}{|c|c|c|c|c|}
\hline \multirow{2}{*}{ Characteristics } & \multicolumn{4}{|c|}{ Factors } \\
\hline & 1 & 2 & 3 & 4 \\
\hline Would like to receive & 0.72 & & & \\
\hline Ordinary-life phenomenon & 0.63 & & & \\
\hline Response & 0.57 & & & \\
\hline Acknowledgement for help & 0.49 & & & 0.45 \\
\hline Might be insincere & & 0.90 & & \\
\hline Might be forehanded & & 0.89 & & \\
\hline Might be mercenary & & 0.85 & & \\
\hline Has a goal & 0.35 & 0.54 & & \\
\hline Expressed materially & & 0.42 & & 0.39 \\
\hline Expression of goodness & & & 0.82 & \\
\hline Expression of warm feelings & & & 0.81 & \\
\hline Attitude & & & 0.65 & \\
\hline Expressed by an action & & & & 0.75 \\
\hline Expressed by words (is verbalized) & & & & 0.66 \\
\hline Would like to express & 0.48 & & & 0.51 \\
\hline Prp.Total & 0.13 & 0.20 & 0.13 & 0.13 \\
\hline Expl.Variance & 2.00 & 2.95 & 2.00 & 1.99 \\
\hline
\end{tabular}

Table 3. Verification of the stability of the factors by means of regression analysis

\begin{tabular}{ccccc}
\hline \multirow{2}{*}{ Factors } & \multicolumn{4}{c}{ Parameters } \\
\cline { 2 - 5 } & $R^{2}$ & $p$ & $F(1 ; \mathbf{1 5})$ & $p$ \\
\hline 1 & 0.37 & $<0.005$ & 10.71 & $<0.005$ \\
2 & 0.38 & $<0.005$ & 11.70 & $<0.005$ \\
3 & 0.42 & $<0.03$ & 12.35 & $<0.03$ \\
4 & 0.52 & $<0.0007$ & 18.15 & $<0.0007$ \\
\hline
\end{tabular}




\section{Identification of gender, age, and ethnic peculiarities of expressing gratitude}

To identify these features the procedure of comparison of individual factor ratings by Student's $t$-test (the values of each factor for each subject) was chosen (Nasledov, 2004/2012). These ratings were obtained during the elaboration of the factor structure discussed previously. The comparison of factor ratings made it possible to determine the quantitative and qualitative expression of each component. It is important to note that in the unipolar factor structure a positive value indicates an intensive expression of quality, while a negative value indicates a less intense expression of quality, but, nevertheless, the quality is present.

Among gender features the difference between the men and the women in the relational and essential components may be noted (Table 4).

Table 4. Differences between the men and the women in the components of gratitude

\begin{tabular}{|c|c|c|c|c|c|}
\hline \multirow{2}{*}{ Components } & \multicolumn{2}{|c|}{ Mean } & \multirow{2}{*}{$t$} & \multirow{2}{*}{$d f$} & \multirow{2}{*}{$p$} \\
\hline & Men & Women & & & \\
\hline Relational & 0.20 & -0.16 & 2.50 & 183 & 0.01 \\
\hline Essential & -0.26 & 0.21 & -3.25 & 183 & 0.001 \\
\hline
\end{tabular}

Age differences are shown in Table 5 (age gradation corresponds to the gradation by E. Erickson).

Table 5. Age differences in the components of gratitude

\begin{tabular}{|c|c|c|c|c|c|}
\hline \multirow{2}{*}{ Components } & \multicolumn{2}{|c|}{ Mean } & \multirow{2}{*}{$t$} & \multirow{2}{*}{$d f$} & \multirow{2}{*}{$p$} \\
\hline & Age 18 (youth) & Age 19-25 (adulthood) & & & \\
\hline Intentional & 0.28 & -0.11 & 2.09 & 76 & 0.04 \\
\hline \multirow{2}{*}{ Components } & \multicolumn{2}{|c|}{ Mean } & \multirow{2}{*}{$t$} & \multirow{2}{*}{$d f$} & \multirow{2}{*}{$p$} \\
\hline & 18 (youth) & 26-56 (maturity) & & & \\
\hline Intentional & 0.28 & -0.05 & 2.04 & 156 & 0.04 \\
\hline Essential & 0.26 & -0.23 & 2.92 & 156 & 0.004 \\
\hline \multirow{2}{*}{ Components } & \multicolumn{2}{|c|}{ Mean } & \multirow{2}{*}{$t$} & \multirow{2}{*}{$d f$} & \multirow{2}{*}{$p$} \\
\hline & 19-25 (adulthood) & 26-56 (maturity) & & & \\
\hline Essential & 0.32 & -0.23 & 2.49 & 130 & 0.01 \\
\hline
\end{tabular}

Differences in the evaluation of gratitude by the criterion of nationality were not found (Table 6). 
Table 6. National differences in the components of gratitude

\begin{tabular}{|c|c|c|c|c|c|}
\hline \multirow{2}{*}{ Components } & \multicolumn{2}{|c|}{ Mean } & \multirow{2}{*}{$t$} & \multirow{2}{*}{$d f$} & \multirow{2}{*}{$p$} \\
\hline & Russians & Tatars & & & \\
\hline Intentional & 0.03 & 0.16 & -0.38 & 155 & 0.71 \\
\hline Relational & 0.01 & -0.17 & 0.56 & 155 & 0.58 \\
\hline Essential & 0.01 & 0.22 & -0.72 & 155 & 0.47 \\
\hline Expressive & -0.11 & 0.48 & -1.87 & 155 & 0.08 \\
\hline \multirow[b]{2}{*}{ Components } & \multicolumn{2}{|c|}{ Mean } & \multirow[b]{2}{*}{$t$} & \multirow[b]{2}{*}{$d f$} & \multirow[b]{2}{*}{$p$} \\
\hline & Russians & Ukrainians & & & \\
\hline Intentional & 0.03 & 0.06 & -0.07 & 154 & 0.95 \\
\hline Relational & 0.01 & -0.41 & 1.25 & 154 & 0.21 \\
\hline Essential & 0.01 & 0.30 & -0.93 & 154 & 0.35 \\
\hline Expressive & -0.11 & -0.49 & 1.08 & 154 & 0.28 \\
\hline \multirow[b]{2}{*}{ Components } & \multicolumn{2}{|c|}{ Mean } & \multirow[b]{2}{*}{$t$} & \multirow[b]{2}{*}{$d f$} & \multirow[b]{2}{*}{$p$} \\
\hline & Russians & Jews & & & \\
\hline Intentional & 0.03 & -0.11 & 0.6 & 164 & 0.55 \\
\hline Relational & 0.01 & 0.31 & -1.3 & 164 & 0.19 \\
\hline Essential & 0.01 & -0.48 & 1.20 & 164 & 0.23 \\
\hline Expressive & -0.11 & 0.71 & 1.16 & 164 & 0.25 \\
\hline \multirow[b]{2}{*}{ Components } & \multicolumn{2}{|c|}{ Mean } & \multirow[b]{2}{*}{$t$} & \multirow[b]{2}{*}{$d f$} & \multirow[b]{2}{*}{$p$} \\
\hline & Tatars & Ukrainians & & & \\
\hline Intentional & 0.16 & 0.06 & 0.20 & 17 & 0.84 \\
\hline Relational & -0.17 & -0.41 & 0.41 & 17 & 0.69 \\
\hline Essential & 0.22 & 0.30 & -0.20 & 17 & 0.84 \\
\hline Expressive & 0.48 & -0.49 & 2.16 & 17 & 0.18 \\
\hline \multirow{2}{*}{ Components } & \multicolumn{2}{|c|}{ Mean } & \multirow{2}{*}{$t$} & \multirow{2}{*}{$d f$} & \multirow{2}{*}{$p$} \\
\hline & Tatars & Jews & & & \\
\hline Intentional & 0.16 & -0.11 & 0.80 & 27 & 0.43 \\
\hline Relational & -0.17 & 0.31 & -1.10 & 27 & 0.28 \\
\hline Essential & 0.22 & -0.48 & 1.34 & 27 & 0.19 \\
\hline Expressive & 0.48 & 0.71 & -0.73 & 27 & 0.47 \\
\hline \multirow{2}{*}{ Components } & \multicolumn{2}{|c|}{ Mean } & \multirow[b]{2}{*}{$t$} & & \\
\hline & Jews & Ukrainians & & $d f$ & $p$ \\
\hline Intentional & -0.11 & 0.06 & 0.41 & 26 & 0.68 \\
\hline Relational & 0.31 & -0.41 & -1.58 & 26 & 0.13 \\
\hline Essential & -0.48 & 0.30 & 1.38 & 26 & 0.18 \\
\hline Expressive & 0.71 & -0.49 & -2.08 & 26 & 0.10 \\
\hline
\end{tabular}




\section{Discussion}

The content interpretation of the factor-analysis results (Table 2) showed the following results.

The first unipolar factor. The main contradiction described in the space of this factor is the desire to receive gratitude from others (society) or the desire to give it back; these desires reflect the social orientation of the individual. Lomov (1984) notes that the orientation of a person is a system-forming function of the person, which manifests itself in the whole system of mental characteristics and conditions of the person: needs, interests, aptitudes, motivational sphere, value orientations, ideals, beliefs, abilities, talents, character, will, and intellectual and emotional features. That is why this factor is called the intentional component (from the Latin: intentio - value, content, desire, intention, purpose): it reflects the expectations and aspirations of the individual. In the space of the factor we see that a heavy load is carried by the desire to receive gratitude from others; however, the factor of unipolarity makes such a desire not dominant but balanced by opposing or neutral characteristics, so the person's behavior as described by this factor will be determined by the dominant individual motivations.

The second unipolar factor. The main content of this factor is the perception of the sociocultural environment as initially exploiting the individual, as insincere, full not of open human interaction but of the status and role-playing games and manipulation that determine the attitude toward gratitude. That is why this factor is called the relational component. The content of the component shows that gratitude is perceived as an exclusively material, physical act, an action, a tool for achieving specific goals. It may be insincere, selfish, sparing; it serves as a means to achieve personal goals. However, the power of expression of the instrumental understanding of gratitude is determined by individual motives too.

The third unipolar factor. This factor reflects the essential understanding of gratitude as an intangible, spiritual, ethical, and moral act of goodness and warmth toward the other. That is why this factor is called the essential component (from the Latin: essentia - the essence, the deeper meaning and significance).

The fourth unipolar factor. This factor includes variables reflecting the understanding of the form in which gratitude should be expressed. That is why this factor is called the expressive component. The variables show that gratitude can be expressed by an act, in words, in any material form and manifestation. In addition, the factor indicates that gratitude can act as a form of need ("It would like to express") and is a manifestation of the support and strengthening of social bonds that are expressed in the form of action in response to another's help.

We see that the elaborated structure of gratitude contains some contradictions. The intentional and relational components are connected to the apparently selfish understanding of human gratitude, which is to obtain something for oneself, to use gratitude as a tool to achieve one's personal goals. The essential component, on the contrary, describes deeply humanized behavior: a kind, gentle, cordial, heartwarming attitude toward the other. The expressive component remains relatively neutral.

Regression analysis of the factors allowed us to clarify the interaction of the components of gratitude. The mutual regression relationship of the intentional and 
relational components $\left(R^{2}=0.38, p<0.007 ; F(1 ; 15)=10.70, p<0.007\right)$ shows that if people tend to receive gratitude from others, they perceive gratitude as a manipulative, selfish, insincere act to a large extent, and vice versa.

The mutual regression relationship of the essential and intentional components $\left(R^{2}=0.42, p<0.03 ; F(1 ; 15)=12.35, p<0.03\right)$ shows that if people have a humanistic understanding of gratitude, they are more willing to express gratitude to the other, and vice versa.

In other words, having a mercenary, egotistical, or spiritually humanized understanding of gratitude may depend on a person's orientation-toward envy, jealousy, greed, lust for power, selfishness, kindness, humility, tolerance, collectivism.

Analysis of the discovered gender and age differences in expressing gratitude shows the following. The men had a more selfish, instrumental understanding (the relational component) of gratitude, while among the women humanistic representations (the essential component) were revealed to a greater extent (Table 4).

In the representatives of the younger generation (youth) romantic and noble ideas of gratitude dominated. They were oriented toward collectivist values, were ready to express heartwarming feelings and kindness to others and to be unselfish, but they expected a similar attitude to be shown toward themselves (Table 5).

Compared with the youth, the young adults (adulthood) expected to receive gratitude less and were less willing to express it. They considered gratitude as a natural phenomenon of life to a lesser extent; they were more selfish, not oriented toward humanistic, collectivist values. In other words, with age noble and romantic motives are replaced by a more expressed social realism. Such an assessment by the respondents in this category may be the result of the experience of receiving benefits previously unavailable through the act of expressing gratitude-for example, in the form of gifts, souvenirs, or services. However, compared with the mature generation, young adults continued to maintain remnant romantic notions about gratitude. They were oriented toward collectivist values and were ready to express warm feelings and kindness to others.

The older adults (maturity) reflected their longer life path and experience with respect to gratitude. They were not oriented toward collectivist values, and their humanistic assessment of gratitude was significantly reduced.

Differences in the evaluation of gratitude by the criterion of nationality were not found (Table 6). With respect to the research results there is a contradiction relating to the understanding of gratitude as a characteristic of national consciousness/mentality, as a cultural phenomenon defined by national and historical features (Borzheeva, 2008). Apparently, the lack of differences in the degree of manifestation of the components of the psychosemantic structure of gratitude can be explained by the peculiarities of expressing gratitude in different cultures. As Mosejko (2014) states, conventional forms of expressing gratitude and the response to it in the English and Russian languages have largely similar semantics and pragmatics. One can speak about differences in the contexts of realizing gratitude and its interactive models - that is, despite the similarity regarding "why" and "how" gratitude is expressed in the two languages, a significant difference relates to the "who," "whom," "where," and "what for" thanks in these cultures. 


\section{Conclusions}

1. This study allowed us to distinguish the content and structure of the semantic space of gratitude and to single out its components: intentional, relational, essential, and expressive. These components are present in the representatives of all the nationalities who participated in the study.

2. A direct link between nationality (ethnicity) and manifestations of and ideas about gratitude was not found.

3. Age and gender significantly influenced the idea of gratitude and its manifestations. The women in the study were more likely than the men to reflect humanistic, collectivist ideas of gratitude. Among representatives of the younger generation (youth) romantic and noble ideas of gratitude dominated. These romantic notions were replaced with realistic ones among the young and mature adults. Although the young adults (adulthood) shared some romantic notions, these ideas disappeared among the older adults (maturity).

4. In general, a mercenary, egotistical, or spiritually humanized understanding of gratitude depends on the orientation of the individual.

\section{References}

Agaev, H. F. (2013). Etnicheskiy religiozniy ekstremizm na Severnom kavkaze kak ugroza natsional'noy bezopasnosti Rossii [Ethical and religious extremism in the Northern Caucasus as a threat to the national safety of the Russian Federation]. Etnosotsium i Mezhnatsionalnaya Kultura [Ethno-Socium and International Culture], 9(63), 155-162.

Bajer, E. S. (2014). Natsionalniy kharakter anglichan [The national character of Englishmen]. In O. M. Barbakov \& U. A. Zobnin (Eds.), Matematicheskie metody i modeli v upravlenii, ekonomike i sotsiologii. Sbornik nauchnykh trudov [Mathematic methods and models in management, economics and sociology. Proceedings] (pp. 14-17). Tyumen, Russia: Tyumen State Oil and Gas University.

Belyakova, I. E., \& Grigoryan, S. G. (2010). Predstavleniya o natsionalnom kharaktere amerikantsa (na materiale romana F. S. Fitsdzheralda "Velikiy Getsbi") [Ideas about American national character (based on the novel by F. Scott Fitzgerald "The Great Gatsby"]. In L. G. Fedyuchenko (Ed.), Tekst i diskurs: Problemy analiza i interpretatsii. Sbornik nauchnykh statey [Texts and discourse. Proceedings]. (pp. 151-154). Tyumen, Russia: Ministry of Education and Science, Russian Federation; Tyumen State University.

Borzheeva, M. A. (2008). Blagodarnost kak forma kulturnoj otzyvchivosti cheloveka: K postanovke problemy [Gratitude as a form of person's cultural responsiveness. Stating the problem]. Almanah Sovremennoj Nauki i Obrazovanija [Almanac of Contemporary Science and Education], 6(2), 39. Retrieved from www.gramota.net/materials/1/2008/6-2/9.html

Bryanskaya, T. I. (2011). Etnokulturnye osobennosti kitayskogo seksizma [Ethno cultural characteristics of the Chinese sexism]. Oykumena. Regionovedcheskie Issledovaniya [Oykumena. Research in Religious Studies], 2, 104-110.

Erokhin, I. Yu. (2013). Kratkij jekskurs istorii i teorii nacionalizma [A brief review of the history and theory of nationalism]. Moscow: Knizhnyj Perekrestok.

Klimenko, L. V. (2011). Etnokulturnye osobennosti samosoznaniya naseleniya yuzhnogo federalnogo okruga [Ethno cultural characteristics of the self-consciousness of the population of the Southern Federal District]. European Social Science Journal, 10(13), 303-313. 
Lewandowskiy, N. G. (1980). O korrektnosti primeneniya faktornogo analiza i o kriteriyakh faktorizatsii [Correct use of the factor analysis and the criteria of factorization]. Voprosy Psihologii [Issues in Psychology], 5, 138-142. Retrieved from http://voppsy.ru/ issues/1980/805/805138.htm.

Lomov, B. F. (1984). Metodologicheskie i teoreticheskie problemy psikhologii [Methodological and theoretical problems of psychology]. Moscow: Nauka.

Mosejko, A. A. (2014). Jetiketnaja model blagodarnosti v anglijskoj i russkoj lingvokulturah. Filologicheskie nauki [Etiquette model of gratitude in the English and Russian linguacultures. Philological sciences]. Voprosy Teorii i Praktiki [issues in Theory and practice], 11(1), 141-144. Retrieved from www.gramota.net/materials/2/2014/11-1/39.html

Muchkaev, E. V. (2012). Etnokulturnye osobennosti Kalmykii v svete orientalizma [Ethno cultural characteristics of Kalmykia throught the perspective of orientalism]. Etnosotsium $i$ Mezhnatsionalnaya Kultura [Ethno-Socium and International Culture], 7(49), 152-154.

Nadya, T. (2011). Strategii konstruirovaniya identichnosti v musul'manskom hip-hope. Raznostoronniy analiz tvorchestva nemetskogo repera Sahiry [Strategies of building identity in musical hip-hop. Versatile analysis of the creativity of the German rapper Sahir]. Pax Islamica, 1(6), 72-88.

Nasledov, A. D. (2012). Matematicheskie metody psikhologicheskogo issledovaniya. Analiz i interpretatsiya dannykh [Mathematic methods of psychological research. Analysis and interpretation of data]. Saint Petersburg: Rech. (Original work published 2004)

Perin, R. L. (2003). Psikhologiya natsionalizma [Psychology of nationalism]. Saint Petersburg: Redaktor.

Rakhmatullina, Z. A. (1999). O nekotorykh osobennostyakh natsionalnogo kharaktera bashkir [Some peculiarities of the Bashkir national character]. Belskie Prostory [Belsk Scopes], 7, $169-179$.

Ri, S. H. (2014). Etnokulturnye smyslovye osobennosti ponimaniya shchastya u russkikh i koreytsev [Ethno cultural characteristics of understanding happiness among Russians and Koreans]. Etnosotsium i Mezhnatsionalnaya Kultura [Ethno-Socium and International Culture], 9(75), 178-181.

Ryazanov, D. S. (2014). Religioznyy ekstremizm, religiozno-politicheskiy ekstremizm i religiozniy fundamentalizm: Obshchee, osobennoe, edinichnoe [Religious extremism, religious and political extremism and religious fundamentalism: Common, peculiar and unique features]. Izvestiya Irkutskogo Gosudarstvennogo Universiteta. Seriya: Politologiya. Religiovedenie [Irkutsk State University Bulletin. Series political and Religious Studies], 7, 177-184.

Sampiev, I. M. (2010). O sootnoshenii natsionalizma, tolerantnosti i demokratii [Correlation between nationalism, tolerance and democracy]. Filosofiya Prava [Philosophy of Law], 2, 37-40.

Sampiev, I. M. (2010). O sootnoshenii natsionalizma, tolerantnosti i demokratii [[Serkin, V. P. (2004). Metody psikhosemantiki [Methods of psychosemantics]. Moscow: ASPEKT-PRESS.

Serkin, V. P. (2008). Metody psikhologii subjektivnoy semantiki i psikhosemantiki: Uchebnoe posobie dlya vuzov [Methods of subjective semantics and psychosemantics. Textbook for universities]. Moscow: Izd-vo PCHELA.

Shiryakov, D. V. (2014) Religiozno-politicheskiy ekstremizm: Sliyanie i vzaimoproniknovenie religioznykh doktrin i politicheskogo ekstremizma [Religious and political extremism: Fusion of religious doctrines and political extremism]. Molodoy Uchyonyy [Young Scientist], $13,219-222$.

Stolin, A. A., Bodalev, V. V., \& Avanesov, V. S. (2002). Obshchaya psikhodiagnostika [General psychodiagnostics]. Saint Petersburg: Rech. 
Tengizova, Zh. A. (2014). Mezhnatsionalnye otnosheniya i religioznyy eks-tremizm [International relationships and religious extremism]. Teoriya i Praktika Obshchestvennogo Razvitiya [Theory and Practice of Social Development], 17, 91-93.

Zhukova, N. V. (2010). Informatsionno-kulturnaya sreda i subjekt poznaniya [Information and cultural environment and the subject of cognition]. In S. A. Minyurova (Ed.), Aktual'nye problemy psikhologii i konfliktologii: Sbornik nauchnykh statey [Urgent issues in psychology and conflictology. Proceedings]. (pp. 55-57). Ekaterinburg, Russia: Ural State Pedagogical University.

Original manuscript received October 19, 2015

Revised manuscript accepted December 12, 2015

First published online June 30, 2016 